\title{
Does the Regional Sense of Social Fairness Really Narrow the Executive-Employee Pay Gap?
}

\author{
Ting Guo \\ School of Management, Jinan University, Guangzhou, China \\ Email: 18390220193@163.com
}

How to cite this paper: Guo, T. (2019) Does the Regional Sense of Social Fairness Really Narrow the Executive-Employee Pay Gap? Modern Economy, 10, 1558-1580. https://doi.org/10.4236/me.2019.106103

Received: April 23, 2019

Accepted: June 25, 2019

Published: June 28, 2019

Copyright (๑) 2019 by author(s) and Scientific Research Publishing Inc. This work is licensed under the Creative Commons Attribution International License (CC BY 4.0).

http://creativecommons.org/licenses/by/4.0/

\begin{abstract}
Based on Chinese traditional Confucianism and under the policy background of "salary limit order", this paper uses tournament theory and social comparison theory to research and analyze the relationship between regional social fairness and the executive-employee pay gap, its effect on employee productivity and the effect of the matching relationship on company performance incentives. Based on the questionnaire survey of China's comprehensive social survey from 2010 to 2016 and the data of all A-share listed companies in China, we find that the regional sense of social fairness will significantly increase the salary gap of companies, and the higher the sense of social fairness, the greater the incentive effect of the salary gap on the production efficiency of ordinary employees, and the correct match between the sense of social fairness and the salary gap will promote the development of the performance of local enterprises. This means that the cultural environment will deeply affect the micro-governance of enterprises. We should attach importance to the role of hidden factors in the executive-employee pay gap, promote the rationalization of the income distribution pattern, and promote the development of the economy stably.
\end{abstract}

\section{Keywords}

Social Fairness, Executive-Employee Pay Gap, Employee Productivity, Company Performance

\section{Introduction}

In ancient China, there were many advocates of "fairness". The ancients talked about equality: reasonable, not partial and not surprising. Confucianism, which 
occupies a dominant position in China's cultural tradition, supports a "balance" under a hierarchical system, which is also the general equality of people's life and wealth. Confucius said that "there is no shortage but inequality" and "there is no poverty". The ideological trend of equality runs through the peasant revolts of past dynasties. The central idea of the peasant revolts in ancient China is to demand the realization of an equal society, which reflects the pursuit of "equality", "fairness" by the public. The Chinese cultural background emphasizes balance and harmony, and the emotional component is greater than the instrumental component. Under such a historical tradition and cultural background, domestic researchers should fully consider the special cultural phenomenon that Chinese attach importance to the sense of social fairness brought about by the executive-employee pay gap.

The 19th National Congress of the Communist Party of China report points out that our people not only put forward higher requirements for material and cultural life, but also have increasingly higher requirements for democracy, the rule of law, fairness, justice, security and the environment. As one of the dimensions of governance, social justice has been paid more and more attention by the national government and the people. Correspondingly, the report proposes to narrow the income distribution gap and achieve a significant reduction in the gap between urban and rural development and the living standards of residents. In order to maintain social stability and quell the sense of social unfairness caused by the large executive-employee pay gap, the government has promulgated a series of mandatory normative policies. For example, starting from January 1, 2015, China's central enterprise wage reform program will start with 200 senior executives from 72 state-owned enterprises and will be implemented. It will also set a wage ceiling for executive staff that has been cut by about eight times. Many countries have recognized the importance of a sense of social fairness and have begun to manage the huge compensation gap by establishing a ceiling for CEO [1].

The sense of social fairness, with its emotional and normative implications, is a part of the cultural environment in which the region is located and guides its behavior through the personal emotions of human beings. Previous studies have shown that cultural environment has an important influence on micro-individual and enterprise behavior. For example, JunHu, Xianzhong Song and Hongjian Wang [2] pointed out that executives' hometown identity has a positive role in promoting corporate environmental governance. Due to the infectivity and continuity of culture and its environment, its binding force and destructive power are often more invisible and profound than formal systems. Therefore, apart from the restriction of the formal system such as laws and regulations on the salary gap, we should not neglect the cultural environment such as social fairness. Although there is an emerging trend of literature research, it has begun to understand the executive-employee pay gap within the top management team [3] [4], between managers and ordinary employees [5] [6], and the economic effects among the ordinary employees of the company [7], in recent decades, the 
theoretical work and laboratory research on the economic effects of fair behavior have also greatly increased, and significant progress has been made. However, contrary to the expectations of Rawls, G. Holcombe and Rabin, few researchers have applied social fairness to economics and management studies, and few scholars have studied its impact on the executive-employee pay gap from the macro-level and informal system, especially the closely related social fairness issues.

Many scholars take the subjective feeling of whether the salary is fair as an opportunity to find an inverted U-shaped relationship between the salary gap and the enterprise efficiency [8] [9]. Coincidentally, Wenjing Li and Yuming $\mathrm{Hu}$ [10] found that the smaller the internal salary gap is, the more it motivates the employees. The larger the salary gap is, the less it motivates the employees, and it not work in the senior executive. However, Zhiqiang Yang and Hua Wang [11] found that the performance improvement brought about by the internal salary gap may just be the manipulation of earnings management, with many noises. The theme of this article is to study the factors that affect the salary gap of the company, instead of directly studying the economic consequences of the salary gap like most literatures. The conclusion of the positive correlation between regional social fairness and salary gap is not quite consistent with the negative correlation between organizational equity and salary gap in many previous literatures, which also breaks the concept of "salary fairness" as we usually think. There are many domestic literatures studying the relationship between salary gap and employee productivity or company performance, but most of the research conclusions conform to the social comparison theory, i.e. the greater the salary gap, the lower the employee productivity or the lower the company performance. This paper uses the indicator of social fairness to confirm that the higher the social equity sense, the greater the incentive effect of salary gap on employee productivity, and conforms to the tournament theory.

Although there are many researches on fairness and executive-employee pay gap, they do not explain the mechanism of executive-employee pay gap affected by social fairness. This paper attempts to formally establish the emotional connection between cultural environment and corporate behavior through the sense of social fairness, and to explore the interactive relationship between macro environment and micro enterprises, so as to more accurately and deeply understand the economic consequences of employees' and executives' sense on fairness of compensation. Therefore, on the basis of the existing literature, starting from the macro cultural environment-the sense of social fairness, rather than just the personal sense of fairness of the enterprise's employees, we should jump out of the framework and pattern of accounting, and study its impact on the micro-field of the enterprise-the salary gap from a more highly and overall perspective. Specifically, there are three problems to be solved: 1) whether the sense of social fairness will affect the salary gap and whether it is consistent with our intuitive sense; 2) Whether the sense of social fairness affects the production efficiency of employees/senior executives through the salary gap; 3) Whether there 
are significant differences in corporate performance caused by the different matching between the sense of social fairness and the salary gap. The above studies supplement the relevant literature on the principles and mechanisms of the executive-employee pay gap research series, it have important reference significance and promotion effect for the in-depth understanding of fairness, and can bring some inspiration and suggestions to policy makers and enterprise managers.

The innovations of this paper are as follows: 1) There is little literature on the impact of social fairness on the executive-employee pay gap. This paper starts from the macro environment and studies its effect on the micro level of the enterprise. 2) Most of the studies only focus on the incentive system of executive compensation, but pay little attention to the incentive system of employee compensation and the importance of employee contribution to the company's performance. This paper re-examines the importance of employee from the perspective of social fairness and provides empirical evidence for employee contribution to the enterprise. 3) This paper attempts to discuss the impact of the mismatch between social fairness and salary gap on the company's performance, thus providing good theoretical suggestions for managers to make strategic and environmental choices.

In order to better understand the research ideas of this article and master the main contents of the article, we have drawn up a research framework named Figure 1, as shown in the following Figure 1.

\section{Literature Review}

\subsection{Sense of Social Fairness}

Most scholars will systematically expound the concept of fairness at the beginning [12] [13], used to explain the fairness of employee compensation and benefits [14] [15], and policy effects on fairness [16] [17]. As early as 1993, Rabin lamented in his article that most current economic models assume that people only pursue their own personal interests and do not care about "social" goals, calling for social fairness to be applied to economics and game theory, and paying attention to the influence of emotion on corporate governance. Relevant documents of organizational behavior and social psychology show that fairness plays a major role in individual cognition and behavior, while fairness theory [18], organizational fairness theory [19] and Social comparison theory [20] have fully elaborated the importance of fairness in enterprise behavior.

The theory of organizational justice studies the role of social justice in the workplace [21]. Literature on organizational justice shows that distribution and procedural justice may have different effects on important outcome variables. Distributive justice can predict personal achievements better, such as job satisfaction, while procedural justice can predict organizational related achievements better, such as organizational commitment. According to the theory of fairness, the degree of motivation of employees comes from subjective comparative 


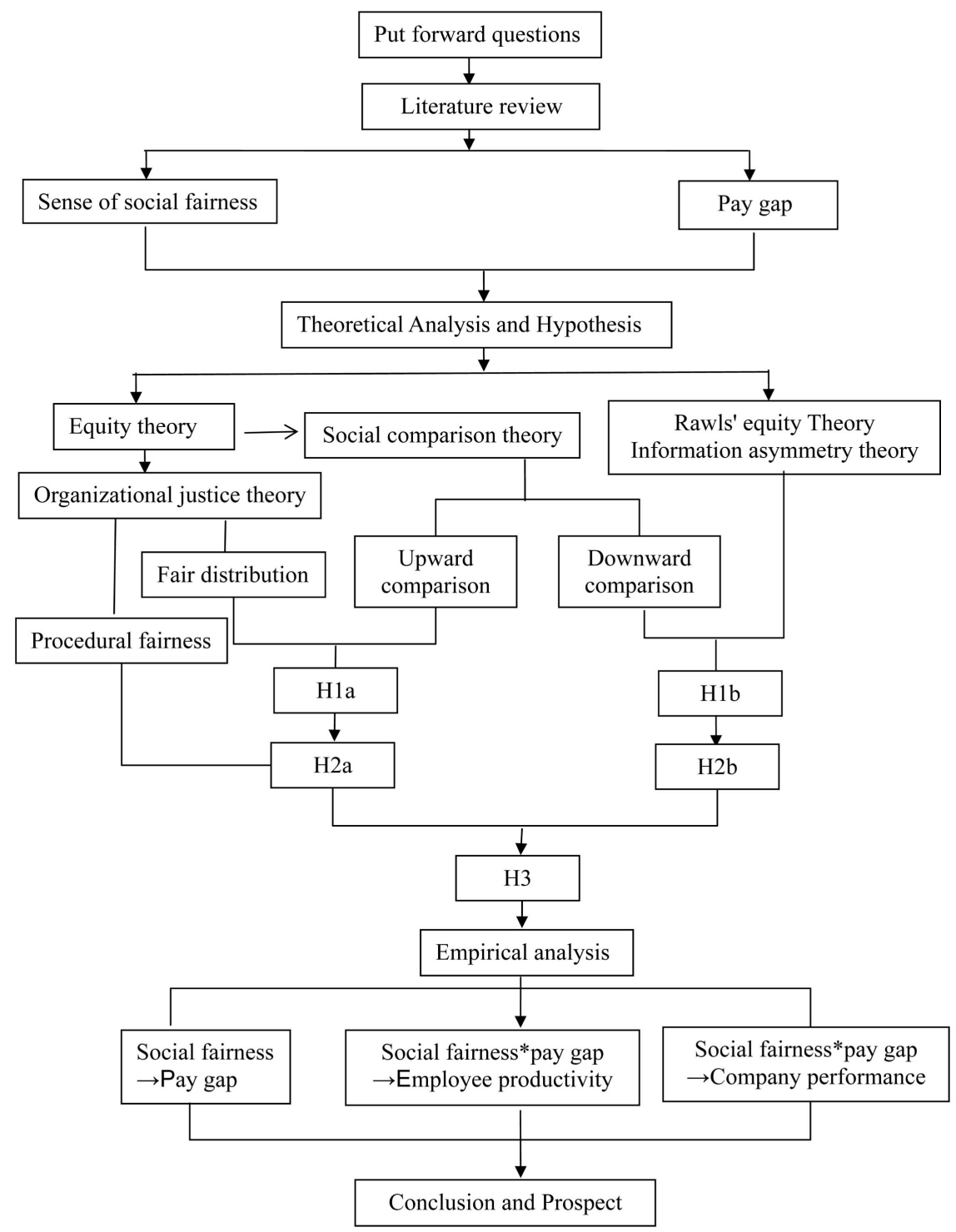

Figure 1. Research framework diagram.

feeling of the proportion of remuneration and investment between themselves and their Referents .In order to determine the fairness of the results, individuals compare this ratio with a significant reference standard, which is based on previous experience, expectations, or the ratio of reference to others [22], if it is below the standard, it is considered unfair.

Some scholars have shifted their research perspective from the sense of fairness of ordinary employees to that of managers [23] [24], exploring performance evaluation [25] [26], peer induction [27], information transparency [28] [29] and others in the enterprise organization fairness. The latest research in the field of accounting has admitted that fairness should be taken into account in the design of management control systems, and the views of fairness in distribution and procedures have been proved to be conducive to the formation of good working behaviors and attitudes [30]. Existing literature has proved that a sense 
of fairness can ease the tension in work and improve the target commitment in budget decision-making [31] [32], improving the organization's civic behavior and role-playing in strategic measurement systems [33], and increasing interpersonal trust. Empirical analysis of fairness in economics is limited to wage dispersion, wage differential compensation and comparative wage rate [34] [35] [36]. Domestic literature focuses on the impact of organizational justice on employees' work attitudes and behaviors [37] [38] [39] and Wansi Chen et al. [40] found that the sense of organizational fairness has a positive impact on the cultivation of harmonious labor relations atmosphere in enterprises. All these researches on fairness emphasize the effect of employees' sense of fairness on the governance of enterprises, while researches on organizational fairness have been abundant for a long time. Almost all the literatures study the influence and regulation of fairness on various aspects, but few scholars have seen through the transmission mechanism of fairness. Most literature studies on fairness are limited to the fair atmosphere brought about by organizations and enterprises, but they do not consider the direct or indirect effects brought about by the sense of social fairness in the region where they are located, nor do they provide any evidence to show why the executive-employee pay gap is fair. Different from the literature on organizational justice, this paper studies the effect of social fairness in the region on the pay gap, which is broader in scope and more invisible in influence. Therefore, it will be more difficult to prove it numerically. What we want to study is how the macro-environment affects the micro-governance of the enterprise, which is different from most literature researches confined to the internal structure of the enterprise. Therefore, we need to carefully study the transmission ways and mechanisms of the impact of social fairness on the enterprise.

\subsection{Executive-Employee Pay Gap}

The general cognition of studying the salary gap is divided into tournament theory and social comparison theory. The tournament theory was first put forward by Lazear and Rosen (1981), and then further developed by Rosen (1986). It suggested that the company establish a salary grade system to encourage employees. A given level of payment in the organizational structure can stimulate the level of employees and induce the level of efforts of employees at the next level [41]. Consistent with the tournament theory, foreign empirical evidence shows that the executive-employee pay gap is positively related to the company's performance [4] [6] [7] [42]. In contrast, Social comparison theory [18] [20] [43], has been widely used in organizational research to explain the response of employees or individual executives to the compensation design system. If their input-output ratio is lower than that of the reference group, the feeling of inequality or deprivation will be stronger. At this time, individuals will try to solve the unequal feeling caused by salary by changing their input or results to themselves or their group, and by changing their actual input or others negative ways. Researchers found that the executive-employee pay gap in the organizational 
structure is too large and is associated with higher turnover rate of managers, less collaboration and lower productivity [5]. Therefore, the high fairness required by social fairness and the unfair environment caused by the large executive-employee pay gap may lead to many high and inefficient behaviors of the company.

Based on the salary gap research in China, part of the research focuses on the relationship between salary gap and performance within the senior management team [44] [45], another part of the research focuses on the impact of the executive-employee pay gap between senior executives and employees on enterprises [46] [47]. ChunLiu, Liang Sun [46], Quanxiong Zhou and Weiping Zhu [47] have all found that the salary gap of state-owned enterprises is positively related to enterprise performance. Some empirical studies have also proved that the salary gap is conducive to enterprise innovation [48], which supports the tournament theory. There are also some empirical studies find that the internal salary gap of enterprises have a negative impact on the company's product quality [49] and enterprise market performance [50] through power and earnings management [11] [51] [52] etc.

We find that both foreign and domestic researches take the executive-employee pay gap as independent variable to study the impact on a certain topic, and the impact of the executive-employee pay gap on enterprise performance has not yet been systematically and clearly understood. Therefore, taking the sense of regional social fairness as the cultural environment background, this paper attempts to study the principle and mechanism of the executive-employee pay gap from the perspective of the sense of social fairness, and further confirms whether employees will really be affected by the sense of regional social fairness, which have behavioral impact on the corporate governance effect, and the promotion/hindrance effect of the matching of the two relationships on corporate performance.

\section{Theoretical Analysis and Hypothesis}

Classical social comparison theory thinks that when there is no objective evaluation standard or source, people evaluate themselves by comparing with others, thus forming a fair understanding. Human nature makes most people prefer fairness, that is, not only pay attention to their own income, but also pay attention to the fairness of income distribution through social comparison with other people's income. Enterprises always adjust their management strategies with the change of external environment. As a kind of cultural environment, social fairness always exerts a subtle influence on people's behaviors and feelings. In areas with high social fairness, enterprises will be affected by this culture and environment. When making salary design, it is necessary to prevent the salary gap from exceeding the tolerance of fairness, especially the tolerance of employees for the salary gap. Classical Adams' fairness theory emphasizes upward comparison, which is consistent with the upward comparison research results of Festinger, that is, subjects are more willing to compare with those who are slightly bet- 
ter than them. The higher the sense of fairness in the region, the higher the demand for necessary respect and fair distribution compared with senior management, so the stronger this resistance will be, because a region with high requirements for social fairness will surely require that the internal salary gap between senior management and employees cannot exceed the public's tolerance range. The higher the sense of fairness, the smaller the tolerance range. In this process, if the salary gap is too large, the employee's salary satisfaction will decrease, which will dampen the employee's enthusiasm for work, lead to the employee's indifference to organizational goals, reduce the cohesion of the enterprise, and thus affect the performance of the enterprise. Many researches on staff salaries's satisfaction found that salary comparison has more explanatory power to employee satisfaction than actual income level [53] [54]. So we put forward the hypothesis:

H1a: The higher the region's sense of social fairness is, relatively the smaller the executive-employee pay gap is.

Rawls' fairness theory should make the following arrangements for social and economic inequality, that is, people can reasonably expect this inequality to be beneficial to everyone. If the system is just and individuals voluntarily accept it and can benefit from it, in this case, individuals should abide by the system. Rawls' principle of justice inspired us. The reason why the sense of social fairness in this region is very high is that people believe that China's system is fair. Most individuals are willing to accept the policy of giving priority to efficiency and benefit from the torrent of China's reform and opening up. Under such circumstances, individuals should abide by this system and accept the gap brought about by this system. Different from the upward perspective of the classical fairness theory, the downward fairness theory holds that when people are under pressure, due to their need for self-improvement, they usually make downward comparisons to reduce the negative emotions caused by pressure, so the positive relationship between social fairness and salary gap is self-evident.

Fairness is not equal to equality, but that income level needs to be proportional to input level and equal to others. However, the executive-employee pay gap only reflects the inequality of individual income level, so the executive-employee pay gap itself does not mean the unfairness of distribution results. As long as the executive-employee pay gap is proportional to the gap between individual input levels, it will not affect the overall sense of fairness. In political economics, respect is the key factor for individuals to feel equal, and the key for society to give respect is a person's position in the production structure. The reason why senior executives have higher salaries is that they are at the top of the production structure, and society should give him full respect and return. Research by some scholars shows that the proportion of income is caused by hard work and talent rather than luck. Therefore, the higher the sense of social fairness in a region, the stronger the defense of senior executives for their own input and output, while ordinary employees are more tolerant of large salary gaps because their income is proportional to their input and is equivalent to others. In the management 
accounting literature, Arnold et al. [55] found that team members with high ability are more inclined to fair distribution based on results, while team members with low ability are more inclined to fair distribution based on procedures. Therefore, ordinary employees are more concerned about procedural fairness than outcome fairness, that is, if social fairness is very high, they will be more tolerant of the executive-employee pay gap, because they are satisfied with the procedural fairness of their pay system. In short, we expect policy makers and managers to be able to judge whether the results are fair based on their ability, instead of simply comparing the actual results with the compensation targets based on the compensation they receive. This comparison, in turn, will affect the sense of fairness in distribution.

Another explanation is that the evaluation of social fairness requires a high demand for information quality. When the net effectiveness of compensation defense increases, management will defend the "legitimacy of results" of compensation through the improvement of managers' compensation-performance sensitivity [56]. Moreover, managers grab private benefits through on-the-job consumption, and there are many invisible "salaries" behind it. Low-paid people will overestimate the social fairness due to information asymmetry, and thus accept the compensation gap caused by information asymmetry with ease. So we put forward the hypothesis:

H1b: The higher the region's sense of social fairness is, relatively the larger the executive-employee pay gap is.

People are willing to sacrifice their material wealth to help those kind people and hurt those who hurt them [57]. According to this statement, as long as employees think that the sense of fairness they feel does not reach the required level of social fairness, they will be considered as not respecting them enough and have the meaning of being sent at will. Compared with other people's low salary, it will be regarded as a denial of self and loss of social respect, and even a sense of social shame. Therefore, it will try its best to avoid excessive salary gap. Wenjing Li et al. [10] found that the salary gap has an incentive effect on employee productivity, but it has no incentive effect on senior executives. The higher the sense of social fairness, the higher the sense of fairness demanded by ordinary employees. If employees think that they have been treated unfairly by the company, they may engage in destructive activities, punish an unfair company and hinder the development of the company. From the above, it can be seen that the sense of fairness will be imperceptibly integrated into our production work, and this kind of character traits that have the power to change behavior preferences can create troubles for the operation of the economy and have a certain impact on the development of enterprises.

H2a: The higher the sense of social fairness, the smaller the incentive effect of the executive-employee pay gap on the productivity of ordinary employees.

If the procedure in the organizational situation is very fair, the senior management defends their talents, and many employees make downward comparisons due to social pressure and psychological needs, the higher the sense of so- 
cial fairness, the stronger the employees' ability to bear the salary gap. According to the tournament theory, a large salary gap can improve the efforts of employees, thus contributing to the company's performance [6] [7], we propose the corresponding assumption:

$\mathrm{H} 2 \mathrm{~b}$ : The higher the sense of social fairness, the greater the incentive effect of the executive-employee pay gap on the productivity of ordinary employees.

The research results of Zhuquan Wang et al. [58] show that enterprises with more serious capital mismatch have lower corporate value (ROA and Tobin Q), which is consistent with previous literature. According to the different matching between the regional social fairness and the salary gap, we believe that the correct matching can promote the local enterprise performance compared with the wrong matching.

H3: Compared with the mismatch between social fairness and salary gap, the correct matching can promote the performance of local enterprises.

\section{Research and Design}

\subsection{Definition of Key Variables}

1) Sense of social fairness

The indicator of social fairness (2010-2013) used in this article comes from a 35 of China's comprehensive social survey-in general, do you think the public is unfair in today's society? The data after 2013 years are based on the data of 2013 years. The Chinese General Social Survey (CGSS) started in 2003 and is the earliest nationwide, comprehensive and continuous academic survey project in China.

2) Enterprise internal salary gap

Referring to the definition of internal salary gap given by QuanxiongZhou, Weiping Zhu [47] and Chun Liu and Liang Sun [46], this paper defines the internal salary gap as follows: internal salary gap $(1)=$ cash paid to and for employees-total annual remuneration of directors, supervisors and senior executives

$$
\text { BWD }=\frac{\text { Top Three Senior Executives Compensation } / 3 \text {-staff salaries }(1)}{\text { Number of Staff }- \text { Number of Senior Executives }}
$$

Among them, the cash paid to and for employees is directly obtained from the "Cash Paid to and for Employees" item in the cash flow statement, and the total amount of staff salaries is obtained after deducting the total amount of executive compensation.BWD is an approximate measure of the internal salary gap estimated in this article, which is generally expressed as the difference between the average personal salary of the senior executives and the average personal salary of the employees.

As pointed out by Chun Liu and Liang Sun [46], this paper also uses the total net salary of employees excluding social basic security expenses such as pension insurance to calculate the internal salary difference. Internal compensation gap $(2)=$ cash paid to and for employees/1.56-total annual compensation for directors, supervisors and senior executives 
NETWD $=\frac{\text { Top Three Senior Executives Compensation } / 3 \text {-staff salaries (2) }}{\text { Number of Employees }- \text { Number of Senior Executives }}$

Among them, NETWD takes into account the internal salary gap after social insurance expenses are eliminated.

In order to eliminate the dimensional influence of the salary gap and make the distribution more normal, this paper takes the natural logarithm of the above salary gap as the main explanatory variable below.

3) Total Factor Productivity

In order to investigate the incentive effect of social fairness on employees through internal salary gap, this paper use the total factor productivity (TFP) to investigate the incentive effect of internal salary gap on employees that refers to Wenjing Li.

$$
\text { OUTPUT }=\beta_{0}+\beta_{1} \mathrm{PPE}+\beta_{2} \text { EMPLOYEE }+\varepsilon
$$

Among them, OUTPUT is the natural logarithm of the enterprise's current year's sales cost plus inventory changes, PPE is the natural logarithm of fixed assets, and EMPLOYEE is the natural logarithm of the number of employees. Total Factor Productivity (TFP) is the residual Epsilon of all A-share listed companies after regression by year and industry according to the model.

4) Enterprise performance

In the relevant financial and accounting research literature, the measurement of enterprise performance includes not only accounting performance but also market performance. However, closely related to this article is Return on Total Assets, whose market value is affected by many factors, and the sense of social fairness may not be so obvious. However, the sense of social fairness is closely related to employees' feelings and their production efficiency, which will have a certain impact on ROA. Therefore, this paper uses Return on Total Assets (ROA) to measure the performance of enterprises.

5) Other Variables

This paper also uses the FIRST and CBD to measure the power of management. In order to control the impact of other factors on the executive-employee pay gap, referring to Zhiqiang Yang, Hua Wang (2014) and Wenjing Li (2012), this paper controls many variables such as return on total assets (ROA), company size(SIZE), financial Lever(LEV), and the number of board members (BDS). Consistent with the existing literature, when studying the impact of internal executive-employee pay gap on enterprise performance, the influence of enterprise characteristics such as enterprise growth (PB), risk (lev) and SIZE is controlled respectively. Table 1 describes the definition and calculation method of each variable. See the following table for details:

\subsection{Construction of Regression Model}

To verify hypothesis 1 , we have established the following regression model:

$$
\mathrm{WD}=\beta_{1}+\beta_{2} \mathrm{a} 35+\sum \beta_{i} \text { control }+ \text { Year }+ \text { Industry }+ \text { Province }+\varepsilon
$$


Table 1. Variable definition.

\begin{tabular}{|c|c|c|c|}
\hline $\begin{array}{l}\text { Variable } \\
\text { property }\end{array}$ & Variable name & $\begin{array}{l}\text { Variable } \\
\text { code }\end{array}$ & Variable description \\
\hline & return on total assets & ROA & Net profit/Average total assets \\
\hline & Company size & Size & Natural logarithm of total assets at the end of the period \\
\hline & Financial leverage & LEV & Total liabilities/total assets at the end of the period \\
\hline & Board size & BDS & Total number of board members \\
\hline & Whether the two positions are integrated & Cbd & $\begin{array}{l}\text { If the general manager and the chairman of the board of } \\
\text { directors are combined, the value will be } 1 \text {, otherwise it will be } 0\end{array}$ \\
\hline & Top management shareholding ratio & Con & Top management shareholding ratio \\
\hline & Degree of separation of two weights & Separation & According to the calculation of CSMAR database \\
\hline \multirow[t]{7}{*}{$\begin{array}{l}\text { Control } \\
\text { Variable }\end{array}$} & Audit quality & TOP4 & $\begin{array}{l}\text { If audited by four major accounting firms, } \\
\text { the value is } 1 \text {; otherwise, the value is } 0\end{array}$ \\
\hline & Information disclosure quality & A_OPION & $\begin{array}{l}\text { If the audit opinion is standard without reservation, } \\
\text { the value is } 1 \text {; otherwise, the value is } 0\end{array}$ \\
\hline & Proportion of independent directors & IDRATIO & Proportion of independent directors \\
\hline & Enterprise risk & Risk & Comprehensive Lever coefficient \\
\hline & Enterprise growth & $\mathrm{PB}$ & Price-to-book ratio at the end of the year \\
\hline & Growth rate of sales revenue & SGROW & $\begin{array}{l}\text { (current sales revenue-previous sales revenue)/ } \\
\text { previous sales revenue }\end{array}$ \\
\hline & $\begin{array}{l}\text { The proportion of shares held } \\
\text { by the largest shareholder }\end{array}$ & First & The proportion of shares held by the largest shareholder \\
\hline
\end{tabular}

At the same time, build model 2 to test hypothesis 2 :

$$
\begin{aligned}
\mathrm{TFP}= & \beta_{0}+\beta_{1} \mathrm{WD}+\beta_{2} \mathrm{a} 35+\beta_{3} \mathrm{a} 35 * \mathrm{WD}+\beta_{4} \mathrm{SGROW}+\beta_{5} \mathrm{~PB} \\
& +\beta_{6} \mathrm{SIZE}+\beta_{7} \mathrm{LEV}+\beta_{8} \text { Year }+\beta_{9} \text { Industry }+\varepsilon
\end{aligned}
$$

In order to verify the impact of the mismatch between social fairness and salary gap on the performance of enterprises, we have constructed model 3:

$$
\begin{aligned}
\mathrm{PERF}= & \beta_{0}+\beta_{1} \mathrm{WD}+\beta_{2} \mathrm{PSM}+\beta_{3} \mathrm{WD} * \mathrm{PSM}+\beta_{4} \mathrm{SGROW}+\beta_{5} \mathrm{~PB} \\
& +\beta_{6} \mathrm{SIZE}+\beta_{7} \mathrm{LEV}+\beta_{8} \text { Year }+\beta_{9} \text { Industry }+\varepsilon
\end{aligned}
$$

PERF is the enterprise performance, which is expressed by accounting performance (ROA), WD is the salary gap, which is measured by BWD and NETWD respectively. PSM is a virtual variable that indicates the matching of social fairness and salary gap, with mismatch being 0 and the rest being 1 . For definitions of other variables, please refer to the control variable table.

\subsection{Data Source}

The construction of social indicators comes from the statistical results of item a 35 of China's comprehensive social survey. Other financial data and data of company characteristics are all from the CSMAR database. Consistent with past practices and literatures, we eliminated the financial and insurance industry and 
ST company, eliminated abnormal values and missing values, and processed all continuous variables with wins or of $1 \%$ and $99 \%$.

\section{Empirical Analysis}

\subsection{Descriptive Analysis}

Table 2 reports the descriptive statistics for variables constructed based on the sample of Chinese listed companies from 2007 to 2016. We can see that the average value of the pay gap indicators is almost all close to 13 , which shows that the salary of senior executives is 13 times that of ordinary employees, far greater than what we call the " 8 -time limit", while the average value of social fairness is 2.97 , close to the three-point value of the option "middle", and the minimum value of employee productivity is less than 0 , which means that some employees are doing negative work or engaging in destructive activities, which cannot bring benefits to the company, but is counterproductive.

\subsection{Regression Analysis}

The main issues we studied are the relationship between social fairness and the pay gap, and whether social fairness affects the economic consequences of the

Table 2. Descriptive statistics.

\begin{tabular}{|c|c|c|c|c|c|}
\hline Variable & Obs & Mean & Std & Min & Max \\
\hline Lnbwd & 13,895 & 12.84 & 0.82 & 6.66 & 16.55 \\
\hline Lnnetwd & 13,983 & 12.94 & 0.76 & 7.55 & 16.03 \\
\hline A35_mean & 14,162 & 2.97 & 0.18 & 2.2 & 3.94 \\
\hline Separation & 13,471 & 8.89 & 103.52 & 0 & 3100 \\
\hline State & 14,162 & 0.41 & 0.49 & 0 & 1 \\
\hline Roa & 13,138 & 0.05 & 0.05 & 0 & 2.93 \\
\hline Size & 14,162 & 22 & 1.28 & 18.22 & 28.51 \\
\hline Bds & 14,135 & 8.76 & 1.76 & 0 & 18. \\
\hline Risk & 14,162 & 2.44 & 4.15 & 0.02 & 264.67 \\
\hline Lev & 14,162 & 0.41 & 0.21 & 0.02 & 0.98 \\
\hline First & 14,162 & 0.36 & 0.15 & 0 & 0.86 \\
\hline Con & 13,709 & 0.08 & 0.15 & 0 & 0.71 \\
\hline Audit & 14,162 & 0.98 & 0.12 & 0 & 1 \\
\hline Big4 & 14,162 & 0.06 & 0.23 & 0 & 1 \\
\hline Iderati & 14,134 & 0.37 & 0.05 & 0.13 & 0.8 \\
\hline Dual & 14,162 & 0.26 & 0.44 & 0 & 1 \\
\hline TFP & 13,060 & 0.01 & 0.71 & -2.96 & 3.41 \\
\hline SGROW & 13,636 & 2.83 & 10.81 & -2.68 & 60.32 \\
\hline $\mathrm{PE}$ & 14,162 & 4.97 & 3.08 & 0.77 & 16.90 \\
\hline $\mathrm{Cf}$ & 13,137 & 1.09 & 4.54 & -16.88 & 30.54 \\
\hline
\end{tabular}


company through the pay gap. However, the main research issues $\mathrm{H} 1$ can be divided into substitution hypothesis and result hypothesis. One is that because we have a high sense of social fairness, we require that the pay gap between senior executives and employees of the company should be controlled within our tolerance, which is called "result", that is, the two are negatively correlated. One is because we believe in the correctness of the company's distribution system and procedures and believe that income and talent are equal, so we feel that social fairness is high, and we don't care about the gap between the two, but we think it is the so-called "fairness" that the gap between the two is within a certain range, which means "substitution", that is, positive correlation. Similarly, the mechanism by which social fairness affects the production efficiency of employees through the pay gap is also divided into the above two different ways, namely $\mathrm{H} 2 \mathrm{a}$ and $\mathrm{H} 2 \mathrm{~b}$. Finally, we use the matching relationship between social fairness and the pay gap to test the impact of social fairness on the company's performance through the pay gap.

In order to test the impact of social fairness on the pay gap, we first did the regression of the two without adding any control variables, then added the control variables to do the regression again, and at the same time controlled the year, industry and province. From Table 3, we can know that the coefficient of social fairness is positive and is significant at a level of $5 \%$, which indicates that the higher people's sense of social fairness, the higher the compensation gap in the company at that time, which means that fairness is not the so-called average, but is proportional to the input. The operation results conform to assumption $\mathrm{H} 2 \mathrm{~b}$. Our regression results show that the Chinese have accepted the compensation gap brought about by the system of giving priority to efficiency and are not pursuing the apparent compensation equality. The size of the company, the number of board members and the proportion of independent directors are positively related to the salary gap, which is consistent with previous literature research. The higher the risk of the company, the smaller the salary gap, which indicates that when the company is in a difficult period of operation or the liquidity of funds is not strong, the company will cut the salary of the company's senior executives to tide over the difficulties.

Table 4 is to consider whether social fairness has an impact on employee productivity through the pay gap. In Table 4, we see that the regression coefficient of the salary gap is significantly negative, which supports the social comparison theory. The internal salary gap is too large to arouse the dissatisfaction of ordinary employees and is not conducive to the cohesion of people's hearts. However, the coefficient of the pay gap and the social equity index that we are concerned about is positive at a significant level of $10 \%$, which indicates that the higher the social equity, the greater the impact of the pay gap on employee productivity. We know that the higher the pay gap is in areas with high social equity, so the coefficient symbol of this cross-product term means that the social equity has a positive effect on employee productivity through the pay gap. Consistent with previous literature, company size, performance indicators and 
Table 3. Social fairness and pay gap.

Baseline regression of the sense of social fairness on firm pay gap. This table reports the regressions of the sense of social fairness outcome variables on firm pay gap and other control variables. Definitions of variables are listed in Table 1.

T-statistics are displayed in parentheses.

${ }^{* *},{ }^{* *}$ and ${ }^{*}$ indicate significance at $1 \%, 5 \%$ and $10 \%$ respectively

\begin{tabular}{|c|c|c|c|c|}
\hline & Lnbwd & Lnnetwd & Lnbwd & Lnnetwd \\
\hline \multirow[t]{2}{*}{ A35_mean } & $0.0923^{* *}$ & $0.0759^{* *}$ & $0.0843^{\star *}$ & $0.0683^{*}$ \\
\hline & $(2.15)$ & (1.97) & $(1.97)$ & (1.79) \\
\hline \multirow[t]{2}{*}{ State } & & & -0.0742 & -0.0639 \\
\hline & & & $(-1.31)$ & $(-1.21)$ \\
\hline \multirow[t]{2}{*}{ Roa } & & & 0.700 & 0.641 \\
\hline & & & (1.59) & $(1.58)$ \\
\hline \multirow[t]{2}{*}{ Size } & & & $0.262^{\star * *}$ & $0.242^{\star * *}$ \\
\hline & & & (12.27) & (12.48) \\
\hline \multirow[t]{2}{*}{$\mathrm{Bds}$} & & & $0.0218^{\star * *}$ & $0.0211^{\star * \star}$ \\
\hline & & & $(2.80)$ & $(2.92)$ \\
\hline \multirow[t]{2}{*}{ Risk } & & & $-0.00588^{* * *}$ & $-0.00541^{* * *}$ \\
\hline & & & $(-3.64)$ & $(-3.60)$ \\
\hline \multirow[t]{2}{*}{ Lev } & & & -0.0927 & -0.0938 \\
\hline & & & $(-1.33)$ & $(-1.51)$ \\
\hline \multirow[t]{2}{*}{ First } & & & -0.0182 & -0.0214 \\
\hline & & & $(-0.15)$ & $(-0.20)$ \\
\hline \multirow[t]{2}{*}{ Con } & & & 0.150 & $0.149^{\star}$ \\
\hline & & & $(1.59)$ & $(1.68)$ \\
\hline \multirow[t]{2}{*}{ Big4 } & & & 0.0801 & 0.0819 \\
\hline & & & $(1.22)$ & $(1.41)$ \\
\hline \multirow[t]{2}{*}{ Ideratio } & & & $0.421^{* *}$ & $0.400^{* *}$ \\
\hline & & & $(2.21)$ & $(2.35)$ \\
\hline \multirow[t]{2}{*}{ Dual } & & & 0.0135 & 0.0120 \\
\hline & & & $(0.62)$ & $(0.63)$ \\
\hline \multirow[t]{2}{*}{ _cons } & $12.28^{\star * *}$ & $12.41^{\star * *}$ & $6.189^{* * *}$ & $6.804^{* * *}$ \\
\hline & $(60.03)$ & $(70.01)$ & $(11.31)$ & (13.95) \\
\hline $\mathrm{N}$ & 13,895 & 13,983 & 12797 & 12,881 \\
\hline
\end{tabular}

employee productivity indicators are positively correlated, while enterprise risks are negatively correlated.

Table 5 shows the results of whether the different matching of social fairness and salary gap is related to the performance of local enterprises, so we set up a virtual variable PSM, which is 1 when the social fairness index is greater than the average value and the salary gap index is greater than the average value, or 1 
Table 4. Social fairness, pay gap and employee productivity.

\begin{tabular}{|c|c|c|}
\hline \multicolumn{3}{|c|}{$\begin{array}{l}\text { Baseline regression of firm Pay Gap on TFP by the sense of Social Fairness. } \\
\text { Definitions of variables are listed in Table } 1 \text {. T-statistics are displayed in parentheses }\end{array}$} \\
\hline & TFP & TFP \\
\hline \multirow[t]{2}{*}{ Lnbwd } & $-0.0556^{\star * *}$ & \\
\hline & $(-2.74)$ & \\
\hline \multirow[t]{2}{*}{ A35_mean * lnbwd } & $0.00605^{\star *}$ & \\
\hline & $(2.32)$ & \\
\hline \multirow[t]{2}{*}{ Lnnetwd } & & $-0.0356^{*}$ \\
\hline & & $(-1.71)$ \\
\hline \multirow[t]{2}{*}{ A35_mean ${ }^{*}$ Lnnetwd } & & $0.00512^{\star *}$ \\
\hline & & $(2.47)$ \\
\hline \multirow[t]{2}{*}{ RoA } & $2.328^{* * *}$ & $2.307^{* * *}$ \\
\hline & $(9.39)$ & $(9.11)$ \\
\hline \multirow[t]{2}{*}{ Size } & $0.111^{\star * *}$ & $0.112^{* * *}$ \\
\hline & $(4.58)$ & $(4.55)$ \\
\hline \multirow[t]{2}{*}{ Bds } & 0.00926 & 0.00744 \\
\hline & $(1.55)$ & $(1.22)$ \\
\hline \multirow[t]{2}{*}{ Risk } & $-0.00410^{* *}$ & $-0.00450^{\star *}$ \\
\hline & $(-2.37)$ & $(-2.42)$ \\
\hline \multirow[t]{2}{*}{ Lev } & $0.336^{* * *}$ & $0.339^{* * *}$ \\
\hline & $(4.52)$ & $(4.60)$ \\
\hline \multirow[t]{2}{*}{ Con } & 0.131 & 0.131 \\
\hline & $(1.37)$ & $(1.37)$ \\
\hline \multirow[t]{2}{*}{ Dual } & $-0.0321^{\star}$ & $-0.0350^{\star}$ \\
\hline & $(-1.70)$ & $(-1.79)$ \\
\hline \multirow[t]{2}{*}{ SGROW } & 0.00940 & 0.00891 \\
\hline & $(0.83)$ & $(0.77)$ \\
\hline \multirow[t]{2}{*}{$\mathrm{Pb}$} & -0.00138 & -0.00116 \\
\hline & $(-0.54)$ & $(-0.45)$ \\
\hline \multirow[t]{2}{*}{$\mathrm{Cf}$} & $-0.511^{\star * \star}$ & $-0.507^{\star * *}$ \\
\hline & $(-6.56)$ & $(-6.37)$ \\
\hline \multirow[t]{2}{*}{ _cons } & $-2.279^{* * *}$ & $-2.500^{* * *}$ \\
\hline & $(-4.07)$ & $(-4.41)$ \\
\hline $\mathrm{N}$ & 7953 & 7989 \\
\hline
\end{tabular}

when the social fairness index is less than the average value and the salary gap index is less than the average value, and the rest is 0 . As shown in the following figure, the salary gap has a positive correlation with the company's performance, 
Table 5. Social fairness, pay gap and company performance.

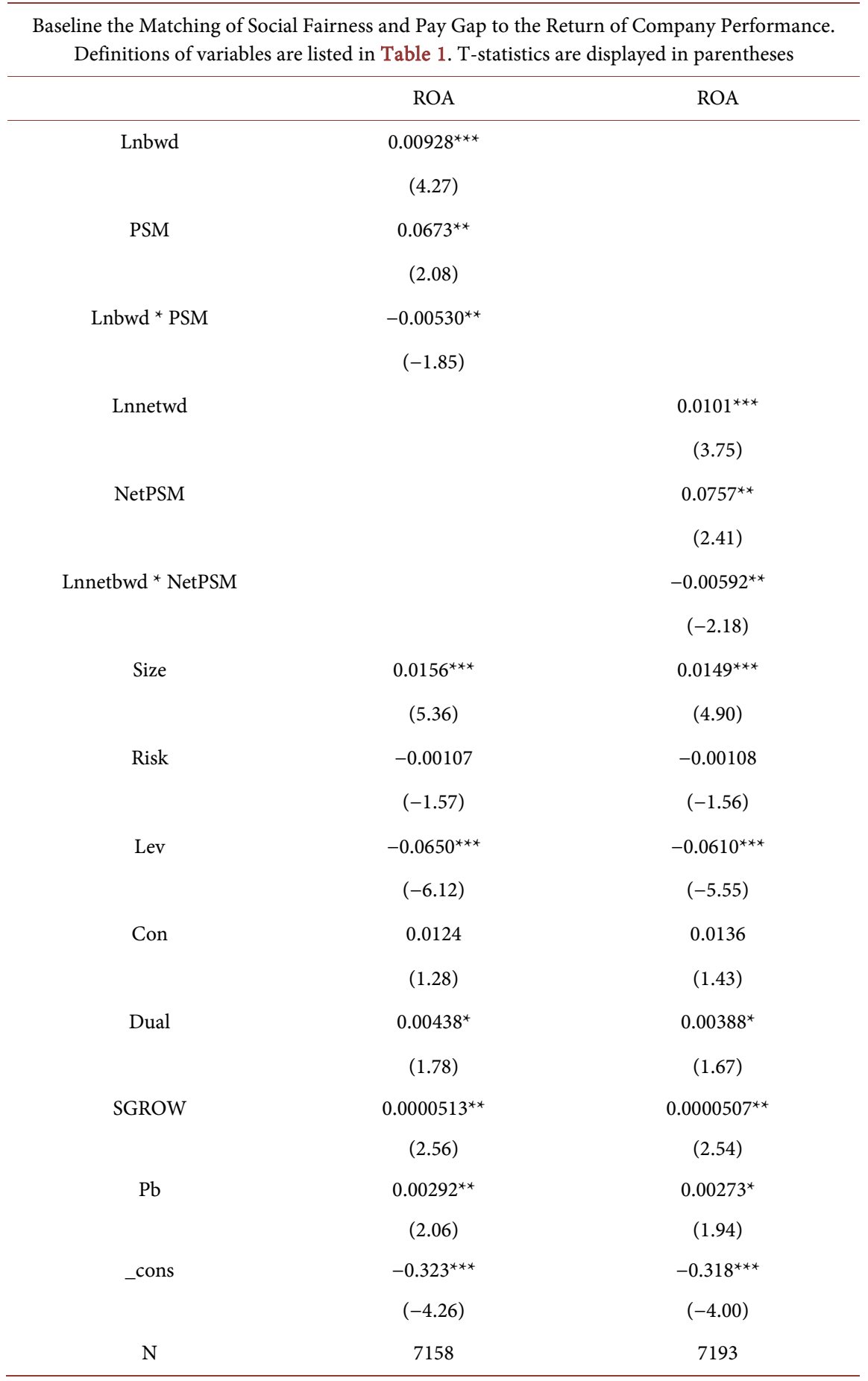

which is in line with the tournament theory. Only by properly opening the salary gap between senior executives and employees can the enthusiasm of the salary competition be aroused, and only those who pay more and those with high abilities can receive appropriate competition rewards. The coefficients of the two PSM indicators are both positive at the significance level of $10 \%$. When the salary gap is not correctly matched with the sense of social fairness, the incentive ef- 
fect of the salary gap on the company's performance is 0.0092, while when psm is 1 , that is, the salary gap is correctly matched with the sense of social fairness, we get the incentive effect of 0.077 , which is 0.067 more than the incentive effect of mismatch. Our $\mathrm{H} 3$ hypothesis has been verified, that is, compared with the regions where the pay gap and social fairness index are mismatched, the regions where the two are correctly matched have higher incentive effect on performance. Naturally, the demand for the pay gap in regions with high sense of social fairness should also be raised to encourage employees to make more contributions to the company. However, if the pay gap is small in regions with high sense of fairness, executives will think that talents cannot be recognized. Employees have no passion to work because there is no competitive reward, so the company's performance will be affected. Our H3 hypothesis has been verified, that is, the companies in the regions where the two PSM indicators are correctly matched perform better than those in the regions where the pay gap and social equity indicators are incorrectly matched. This result reveals that macro-environment and micro-enterprise are an organic whole. We cannot ignore macro-environment or macro-factors and consider micro-enterprise Separately. When formulating the salary system, the manager should clearly understand the employees' demand for salary and the overall sense of fairness in the general environment, and correctly match the local sense of social fairness with the pay gap of the company in order to better promote the economic development of the company.

\section{Conclusion and Prospect}

According to a recent report (2015) by Oxfam, an international anti-poverty charity, the world's richest $1 \%$ controls $50 \%$ of the world's wealth. The widening gap between rich and poor has led to social conflicts and undermined economic growth and regional stability. With the economic pace of "efficiency" gradually transforming to "fairness", studying the influence of regional cultural environment on the compensation gap of the company and exploring its effect on the productivity of employees and the performance of the company provide further research direction for relevant scholars, supplement relevant literature research, and provide ideas for the planning and management of company managers and government policy makers. The results of the study show that, first, if the social fairness in the region is higher, the salary gap of enterprises is relatively larger; Second, the higher the sense of social fairness in the region, the greater the incentive effect of the executive-employee pay gap on the productivity of ordinary employees; Third, compared with the mismatch between social fairness and salary gap, the correct matching can promote the performance of local enterprises. Our research shows that the relationship between social fairness and the executive-employee pay gap is not the average we usually think, but is consistent with our distribution system, that is high salaries matched with high talents and more capable. The incentive effect on employees is not the unequal psychology, but 
the incentive temptation of the championship is more inspiring. When the government and managers formulate policies or design systems to control the salary gap between senior executives and employees, they should not only narrow the superficial digital gap within a reasonable range, but also combine the regional social fairness sense of the region, seriously consider the subtle influence brought by the regional cultural environment, and pay attention to the different psychological feelings of our employees for fairness, so as to ensure the relative fairness of the internal distribution of the company according to local conditions. Only by correctly recognizing the match between the sense of social fairness in the region and the salary gap of the company and integrating the macro environment into the research of micro-governance of the company can promote the stable development of the economy, and make the society better.

\section{Conflicts of Interest}

The author declares no conflicts of interest regarding the publication of this paper.

\section{References}

[1] Chao, C.C., Nabin, M., Nguyen, X. and Sgro, P.M. (2016) Wage Inequality and Welfare in Developing Countries: Privatization and Reforms in the Short and Long Run. International Review of Economics Finance, 42, 474-483. https://doi.org/10.1016/j.iref.2015.10.023

[2] Hu, J., Song, X. and Wang, H. (2017) Informal System, Hometown Identity and Corporate Environmental Governance. Management World, 3, 76-93. http://kns.cnki.net/kns/brief/default_result.aspx

[3] Lee, K.W., Lev, B. and Yeo, G.H.H. (2008) Executive Pay Dispersion, Corporate Governance, and Firm Performance. Review of Quantitative Finance and Accounting, 30, 315-338. https://link.springer.com/article/10.1007/s11156-007-0053-8 https://doi.org/10.1007/s11156-007-0053-8

[4] Kale, J.R., Reis, E. and Venkateswaran (2009) A Rank-Order Tournaments and Incentive Alignment: The Effect on Firm Performance. Journal of Finance, 64, 1479 1512. https://doi.org/10.1111/j.1540-6261.2009.01470.x

[5] Firth, M., Leung, T., Rui, O. and Na, C. (2015) Relative Pay and Its Effects on Firm Efficiency in a Transitional Economy. Journal of Economic Behavior \& Organization, 110, 59-77. https://doi.org/10.1016/j.jebo.2014.12.001

[6] Banker, R.D., Bu, D. and Mehta, M.N. (2016) Executive-Employee Pay Gap and Performance in China. Abacus, 52, 501-531. https://doi.org/10.1111/abac.12082

[7] Lallemand, T., Plasman, R. and Rycx, F. (2004) Intra-Firm Wage Dispersion and Firm Performance: Evidence from Linked Employer-Employee Data. Kyklos, 57, 533-558. https://doi.org/10.1111/j.0023-5962.2004.00268.x

[8] Dai, Y., Kong, D. and Xu, J. (2017) Does Fairness Breed Efficiency? Pay Gap and Firm Productivity in China. International Review of Economics and Finance, 48, 406-422. https://doi.org/10.1016/j.iref.2017.01.003

[9] Zhong, R. (2017) Research on Executive-Employee Compensation Incentive and Fairness in Enterprise Performance-Based on Empirical Data of A-Share Manufacturing Listed Companies. Contemporary Economy, 25, 102-105. 
http://kns.cnki.net/kns/brief/default_result.aspx

[10] Li, W. and Hu, Y. (2012) Who Is Motivated by the Internal Salary Gap in StateOwned Enterprises? Economic Research Journal, 12, 125-135.

http://kns.cnki.net/kns/brief/default_result.aspx

[11] Yang, Z. and Wang, H. (2014) Internal Compensation Gap, Ownership Concentration and Earnings Management Behavior-Based on Comparative Analysis of Compensation between Interal Top Management Team and Top ManagementEmployees. Accounting Research, 9, 57-65. http://kns.cnki.net/kns/brief/default_result.aspx

[12] Holcombe, R.G. (1983) Applied Fairness Theory: Comment. The American Economic Review, 73, 1153-1156.

[13] Cappelen, A.W., Hole, A.D., Sørensen, E.Ø. and Tungodden, B. (2007) The Pluralism of Fairness Ideals: An Experimental Approach. The American Economic Review, 97, 818-827. https://doi.org/10.1257/aer.97.3.818

[14] Akerlof, G.A. and Yellen, J.L. (1988) Fairness and Unemployment. The American Economic Review, 78, 44-49.

[15] Tortia, E.C. (2008) Worker Well-Being and Perceived Fairness: Survey-Based Findings from Italy. The Journal of Socio-Economics, 37, 2080-2094.

https://doi.org/10.1016/j.socec.2007.10.005

[16] Green, D.A. (2014) What Is a Minimum Wage for? Empirical Results and Theories of Justice. Canadian Public Policy, 40, 293-314. https://doi.org/10.3138/cpp.2014-058

[17] Persico, N. (2002) Racial Profiling, Fairness, and Effectiveness of Policing. The American Economic Review, 92, 1472-1497.

https://doi.org/10.1257/000282802762024593

[18] Adams, J.S. (1965) Infairness in Social Exchange. Advances in Experimental Social Psychology, 2, 267-299. https://doi.org/10.1016/S0065-2601(08)60108-2

[19] Colquitt, J.A., Wesson, M.J., Porter, C.O.L.H., Conlon, D.E. and Ng, K.Y. (2001) Justice at the Millennium: A Meta-Analytic Review of 25 Years of Organizational Justice Research. Journal of Applied Psychology, 86, 425-445.

https://doi.org/10.1037/0021-9010.86.3.425

[20] Festinger, L. (1954) A Theory of Social Comparison Processes. Human Relations, Studies towards the Integration of the Social Sciences, 7, 117-140. https://doi.org/10.1177/001872675400700202

[21] Greenberg, J. (1990) Organizational Justice: Yesterday, Today, and Tomorrow. Journal of Management, 16, 399-432. https://doi.org/10.1177/014920639001600208

[22] Goodman, P.S. (1974) An Examination of Referents Used in the Evaluation of Pay. Organizational Behavior and Human Performance, 12, 170-195. https://doi.org/10.1016/0030-5073(74)90045-2

[23] Hartmann, F. \& SlapniCar, S. (2012) The Perceived Fairness of Performance Evaluation: The Role of Uncertainty. Management Accounting Research, 23, 17-33. https://doi.org/10.1016/j.mar.2011.10.004

[24] Fong, E.A. (2010) CEO Pay Fairness as a Predictor of Stakeholder Management. Journal of Business Research, 63, 404-410. https://doi.org/10.1016/j.jbusres.2009.04.017

[25] Voußema, L., Kramerb, S. and Schäffera, U. (2016) Fairness Perceptions of Annual Bonus Payments: The Effects of Subjective Performance Measures and the Achievement of Bonus Targets. Management Accounting Research, 30, 32-46. 
https://doi.org/10.1016/j.mar.2015.10.001

[26] Gupta, A., Raman, K. and Shang, C.G. (2018) Social Capital and the Cost of Equity. Journal of Banking and Finance, 87,102-117. https://doi.org/10.1016/j.jbankfin.2017.10.002

[27] Ho, T.-H. and Su, X. (2009) Peer-Induced Fairness in Games. The American Economic Review, 99, 2022-2049. https://doi.org/10.1257/aer.99.5.2022

[28] Hartmann, F.G.H. and Slapnicar, S. (2012) Pay Fairness and Intrinsic Motivation: The Role of Pay Transparency. The International Journal of Human Resource Management, 23, 4283-4300. https://doi.org/10.1080/09585192.2012.664962

[29] Sgin, E.I. and Sopher, B. (2015) Information Transparency, Fairness and Labor Market Efficiency. Journal of Behavioral and Experimental Economics, 58, 33-39. https://doi.org/10.1016/j.socec.2015.06.005

[30] Cugueró-Escofet, N. and Rosanas, J.M. (2013) The Just Design and Use of Management Control Systems as Requirements for Goal Congruence. Management Accounting Research, 24, 23-40. https://doi.org/10.1016/j.mar.2012.11.001

[31] Lau, C.M. and Tan, S.L.C. (2006) The Effects of Procedural Fairness and Interpersonal Trust on Job Tension in Budgeting. Management Accounting Research, 17, 171-186. https://doi.org/10.1016/j.mar.2005.10.001

[32] Wentzel, K. (2002) The Influence of Fairness Perceptions and Goal Commitment on Managers' Performance in a Budget Setting. Behavioral Research in Accounting, 14, 247-271. https://doi.org/10.2308/bria.2002.14.1.247

[33] Burney, L.L., Henle, C.A. and Widener, S.K. (2009) A Path Model Examining the Relations among Strategic Performance Measurement System Characteristics, Organizational Justice, and Extra- and In-Role Performance. Accounting, Organizations and Society, 34 305-321. https://doi.org/10.1016/j.aos.2008.11.002

[34] Frank, R.H. (1984) Are Workers Paid Their Marginal Products? American Economic Review, 74, 549-571.

[35] Stark, O. (1990) A Relative Deprivation Approach to Performance Incentives in Career. Games and Other Contests. Kyklos, 43, 211-227. https://doi.org/10.1111/j.1467-6435.1990.tb00208.x

[36] Clark, E.A. and Oswald, A.J. (1996) Satisfaction and Comparison Income. Journal of Public Economics, 61, 359-381. https://doi.org/10.1016/0047-2727(95)01564-7

[37] Zhang, Y. (2014) Effect of Fairness in Performance Appraisal on Anti-Production Behavior: Regulating Effect of Exchange Consciousness. Management Review, 26, 158-1670. http://www.cnki.net

[38] Ma, C., Xue, D. and Gross Weight Lin (2014) The Effect of Organizational Justice on Turnover Intention. Journal of South China Normal University (Social Science Edition), 1, 74-82.

[39] Zhang, Y., Xie, Y. and Wang, L. (2015) Organizational Justice and Employee Work Behavior: Mediating Role of Psychological Security. Journal of Peking University (Natural Science Edition), 51, 180-186. http://www.cnki.net

[40] Chen, W., Ding, J. and Yu, Y. (2013) Influence of Participatory Management on Harmonious Labor Relations: Mediating Effect of Organizational Justice and Intergenerational Regulation. Nankai Business Review, 16, 47-58. http://www.cnki.net

[41] Rajgopal, S. and Srinivasan, S. (2006) Pay Gap in the Executive Suite. Working Paper.

[42] Coombs, J.E. and Gilley, K.M. (2005) Stakeholder Management as a Predictor of CEO Compensation: Main Effects and Interactions with Financial Performance. 
Strategic Management Journal, 26, 827-840. https://doi.org/10.1002/smj.476

[43] Martin, J. (1981) Relative Deprivation: A Theory of Distributive Injustice for an Era of Shrinking Resources. Graduate School of Business, Stanford University, Stanford.

[44] Chen, Z. and Zhang, M. (2006) Research on Differential Compensation within Senior Management. China Accounting Review, 4, 15-28. http://www.cnki.net

[45] Lin, J., Huang, Z. and Sun, Y. (2003) Pay Gap on Interal Top Management Team, Corporate Performance and Governance Structure. Journal of Economic Research, No. 4, 31-40. http://www.cnki.net

[46] Liu, C. and Sun, L. (2010) Pay Gap and Corporate Performance: Empirical Evidence from Listed Companies of State-Owned Enterprises. Nankai Business Review, No. 2, 30-39. http://www.cnki.net

[47] Zhou, Q. and Zhu, W. (2010) Research on Championship Incentive Effect and Restrictive Factors of State-Owned Enterprise. Economics (Quarterly), 9, 571-596. http://www.cnki.net

[48] Xu, M., Kong, G. and Kong, D. (2017) Does Wage Justice Hamper Creativity? Pay Gap and Firm Innovation in China. China Economic Review, 44, 186-202. https://www.sciencedirect.com/science/article/pii/S1043951X17300561 https://doi.org/10.1016/j.chieco.2017.04.003

[49] Cowherd, D.M. and Levine, D.I. (1992) Product Quality and Pay Fairness between Lower-Level Employees and Top Management: An Investigation of Distributive Justice Theory. Administrative Science Quarterly, 37, 302-320.

https://www.jstor.org/stable/2393226

https://doi.org/10.2307/2393226

[50] Siegel, P.A. and Hambrick, D.C. (1996) Business Strategy and the Social Psychology of Top Management Teams. Advances in Strategic Management, 13, 91-119.

[51] Lu, R. (2007) Management Power, Executive-Employee Pay Gap and Performance. South China Journal of Economics, No. 7, 60-69. http://www.cnki.net

[52] Quan, X., Wu, S. and Wen, F. (2010) Management Power, Private Benefits and Compensation Manipulation. Journal of Economic Research, No. 11, 73-87.

http://www.cnki.net

[53] Williams, M.L. (1995) Antecedents of Employee Benefit Level Satisfaction: A Test of a Model. Journal of Management, 21, 1097-1128.

https://www.sciencedirect.com/science/article/pii/0149206395900241 https://doi.org/10.1177/014920639502100605

[54] Williams, M.L., McDaniel, M.A. and Nguyen, N.T. (2006) A Meta-Analysis of the Antecedents and Consequences of Pay Level Satisfaction. Journal of Applied Psychology, 91, 392-413. https://psycnet.apa.org/record/2006-03206-011 https://doi.org/10.1037/0021-9010.91.2.392

[55] Arnold, M.C., Hannan, R.L. and Tafkov, I.D. (2014) Non-Verifiable Communication Inhomogeneous and Heterogeneous Teams. Unpublished Working Paper. https://doi.org/10.2139/ssrn.2312800

[56] Xie, D., Lin, L. and Chen, Y. (2012) Compensation Committee Independence and Higher Manager Compensation-Performance Sensitivity-Analysis and Test Based on Compensation Defense Hypothesis. Management World, 1, 121-140. http://www.cnki.net

[57] Rabin, M. (1993) Incorporating Fairness into Game Theory and Economics. The American Economic Review, 83, 1281-1302.

https://www.jstor.org/stable/pdf/2117561.pdf 
[58] Wang, Z., Duan, B., Wang, Y. and Chen, G. (2017) Capital Mismatch, Asset Specificity and Company Value-From the Perspective of Reclassification of Business Activities. China Industrial Economics, 3, 120-138. http://www.cnki.net 